\title{
Piety, Power, and Place in Central and East Asian Buddhism
}

\author{
Carmen Meinert and Henrik H. Sørensen
}

The present volume is the proceedings of the start-up conference "Establishing of Buddhist Nodes in Eastern Central Asia 6th to 14th C. Part I: Sacred Space, Pilgrimage, Patronage, Legitimation Strategies" of the BuddhistRoad project, which was held at Ruhr-Universität Bochum on 23-25 May, 2018..$^{1}$ The themes chosen for this volume are similar to those that constitute the research clusters of the BuddhistRoad project, and are thus part of an attempt at encompassing the salient and observable features that manifested in the Buddhist centres along the networks of the Silk Road and beyond. ${ }^{2}$ At the same time, these themes reflect the research interests and competences of the project's participants. It goes without saying that a volume such as the present one cannot cover all relevant topics pertaining to Silk Road studies. The present volume is not intended to do so. Nor does this collection of articles deal with all of the many linguistic fields of Central Asia. What we seek to do here is to provide a series of case studies, each of which highlights specific aspects of the history of Buddhism along the Silk Road.

Even though there are numerous articles and historical studies on selected aspects of Buddhism at various sites, there is not a single, book-length recent study of Buddhism on the Silk Road in any Western language. Given the great interest that Central Asia has had in scholarly circles for more than a century, one expects that at least one monograph on the region's most influential and major religion would have been written by now. However, this unfortunate state of affairs underscores the difficulties of coming to terms with the Silk Road and Buddhism in Eastern Central Asia under the cover of a single study. Surely there are enough primary source materials and archaeological data

1 The conference programme is available on the BuddhistRoad website: $<$ https://buddhistroad. ceres.rub.de/en/activities/organised-conferences/>.

2 A project report sketching the overall research agenda of the project was recently published in the open access article: BuddhistRoad Team, "Dynamics in Buddhist Transfer in Eastern Central Asia 6th-14th Centuries: A Project Report by BuddhistRoad Team," Medieval Worlds 8 (2018): 126-134. The article is available here: <https://doi.org/10.1553/medievalworlds_ no8_2018s126>. The reader interested in the overall research agenda and design of the project may kindly be referred to this article. 
available by now to at least produce an introductory study of Buddhism on the Silk Road, even if it requires a potential author to be able to cover several linguistic fields. ${ }^{3}$

With this background in mind, the present volume, broadly conceptualised, deals with the construction of power, secular as well as religious, expressed through processes of legitimation, including patronage and donations, the establishment of so-called sacred spaces, and the associated practice of pilgrimage. However, while the issues of legitimation and patronage play directly into questions of power and its preservation, the issues concerning sacred space and pilgrimage are only related to them in a secondary manner. Politically, legitimation strategies involve religious piety, genuine and pretended, a high degree of social and cultural positioning, and a seemingly strong desire to present oneself as a paragon of civilising qualities.

The interplay between religion and secular power, as it played out in the Buddhist centres located along the Silk Road during the 6th to 14th century, often followed a model where mutual benefit played a crucial role. The Buddhist religion was dependent upon benevolent rulers, who extended their graces and economic muscle to sustain religious establishments, sponsor

3 For a general overview of Central Asian history see Christopher I. Beckwith, Empires of the Silk Road. A History of Central Eurasia from the Bronze age to the Present (Princeton: Princeton University Press, 2009); and for a survey of the history of Buddhism and its contact with Islam in Central Asia see Johan Elverskog, Buddhism and Islam on the Silk Road (Philadelphia: University of Pennsylvania Press, 2010). It should be noted, however, that the latter book is not a result of studying primary sources perse. An important resource on Buddhism's material culture in Central Asia up to and slightly after 6oo, mainly dealing with the westernmost sites is: Marylin Martin Rhie, Early Buddhist Art of China and Central Asia, vol. 2 (Leiden, Boston, Köln: Brill, 2002). A useful discussion of the Silk Road as an artery for diplomacy, much of it relevant to the history of Buddhism in the region, is found in: Tansen Sen, Buddhism, Diplomacy, and Trade: The Realignment of India-China Relations, 600-1400 (Honolulu: University of Hawai'i Press, 2003). An example of a collection of Chinese articles on the economic aspects of the Silk Road presenting modern editions of recovered Chinese documents with primary sources relevant to our understanding of life in Dunhuang and Turfan up to the beginning of the gth century is: Han Guopan 韩国磐, ed., Dunhuang Tulufan chutujing jiwen shuyanjiu 敦煌吐鲁番出土经济文书研究 [Studies on the Documents Related to Economy Unearthed from Dunhuang and Turfan] (Xiamen:Xiamen daxue chubanshe, 1986). A thoughtful overview that discusses trade, history, transmission of aspects of material culture, networks and the overall realities of the Silk Road in medieval times, i.e. in the timeframe of our project, is: David Summers, "Epilogue: The Silk Road as Real Space," in China and Beyond in the Medieval Period: Cultural Crossings and Inter-Regional Connections, ed. Dorothy C. Wong and Gustav Heldt (New Delhi: Manohar, Cambria Press, and NSC ISEAS, 2014), 421-425. Last but not least, an overview of the history of the Silk Road from Samarkand to Chang'an, but one which addresses the ubiquitous importance of Buddhism in most of the important cultural nodes along the Silk Road, especially its central and eastern parts, with a rudimentary introduction to the Buddhist history of the Eastern Central Asia, is: Valerie Hansen, The Silk Road: A New History (Oxford: Oxford University Press, 2012). 
rituals and the production of holy scriptures, and additionally promote religious leaders, while Buddhism on its part lent its prestige, salvific promises (including divine protection), and its role as a shared, stabilising factor to the glory of the various rulers. This was particularly important in the multi-cultural setting of the area we are dealing with, where Buddhism's role as a unifying factor also involved identity politics and negotiating among competing ethnic and/or religious groups. ${ }^{4}$

Therefore, the dynamics of religious patronage operated between the three societal fields of politics, economics, and religion. ${ }^{5}$ However, not all patronage activities that took place at the interface of these three fields necessarily entailed religious results. Here, one may define religious patronage as motivated by, on the one hand, good (karmic) results, and on the other, a need to underline one's own position-either as a ruler or as a leading figure in society. In other words, patronage is a concern with achievements that were either purely religious (in the sense of attainment of Buddhist merit, enlightenment, etc.), or more politically motivated as a means of promoting one's own power. The latter may also enhance divine legitimation of a local ruler, and as such function as one aspect of a broader legitimation strategy. It is only through longterm institutional patronage, supported by private donations, that a cultural region is gradually and thoroughly transformed into a religious-cultural entity — as seen in the lands in Eastern Central Asia, which eventually developed a plethora of Buddhist sacred sites and routes of pilgrimage. In short, there was hardly a kingdom, empire, or domain in Eastern Central Asia (see map o.1) where Buddhism thrived, in which these factors did not play out to greater or lesser extents.

The emergence of Buddhist sites or 'sacred spaces' along the Silk Road may, of course, be seen as simply a reflection of the steady eastward expansion of the religion across Eastern Central Asia towards China, and a counter-wave

4 Relational definitions of identity presuppose the (ethnic/religious) 'other.' For further reference, see among many others, Siniša Malešević, Identity as Ideology. Understanding Ethnicity and Nationalism (New York: Palgrave Macmillan, 2006).

5 Our analysis of religious patronage at the intersection of the three societal fields of religion, politics, and economics is inspired by the CERES research programme. The interplay between religious semantics and social structures in the emergence of a religious field is described by our colleague Volkhard Krech, "Dynamics in the History of Religions-Preliminary Considerations on Aspects of a Research Programme," in Dynamics in the History of Religions between Asia and Europe. Encounters, Notions, and Comparative Perspectives, ed. Volkhard Krech and Marion Steinicke (Leiden, Boston: Brill, 2012), 15-70. For a further discussion of contemporary scholarship which tends to assume that the term 'religion,' if conceived as a social field distinct from politics and economy, is a product of the Western history of religions see Jonathan Z. Smith, "Religion, Religions, Religious," in Critical Terms for Religious Studies, ed. Mark C. Taylor (Chicago, London: University of Chicago Press, 1998), 269-284. 


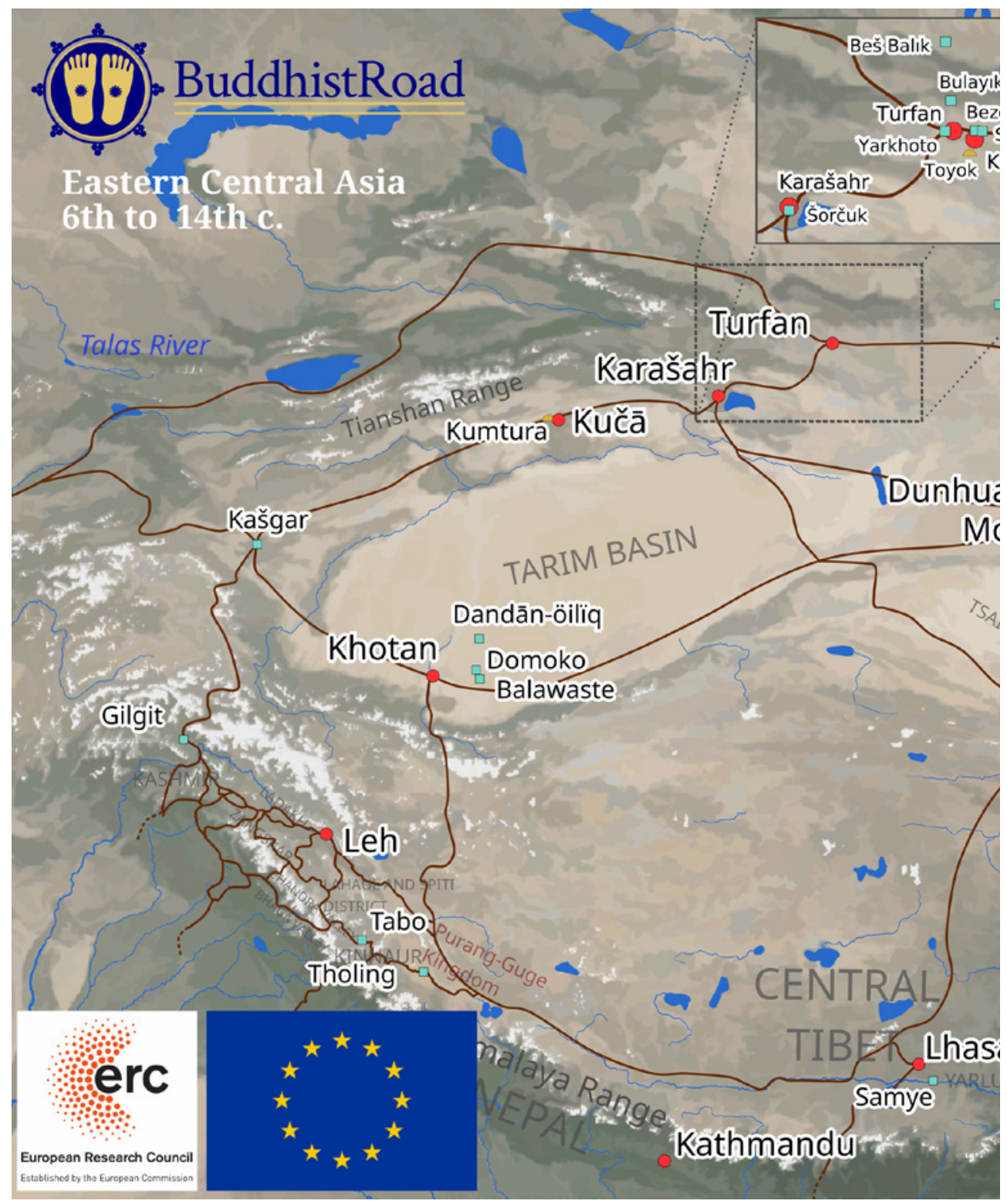

MAP $0.1 \quad$ Network of Buddhist nodes in Eastern Central Asia.

(C) ERC PROJECT BUDDHISTROAD. THE MAP WAS PREPARED BY JÜRGEN SCHÖRFLINGER. 


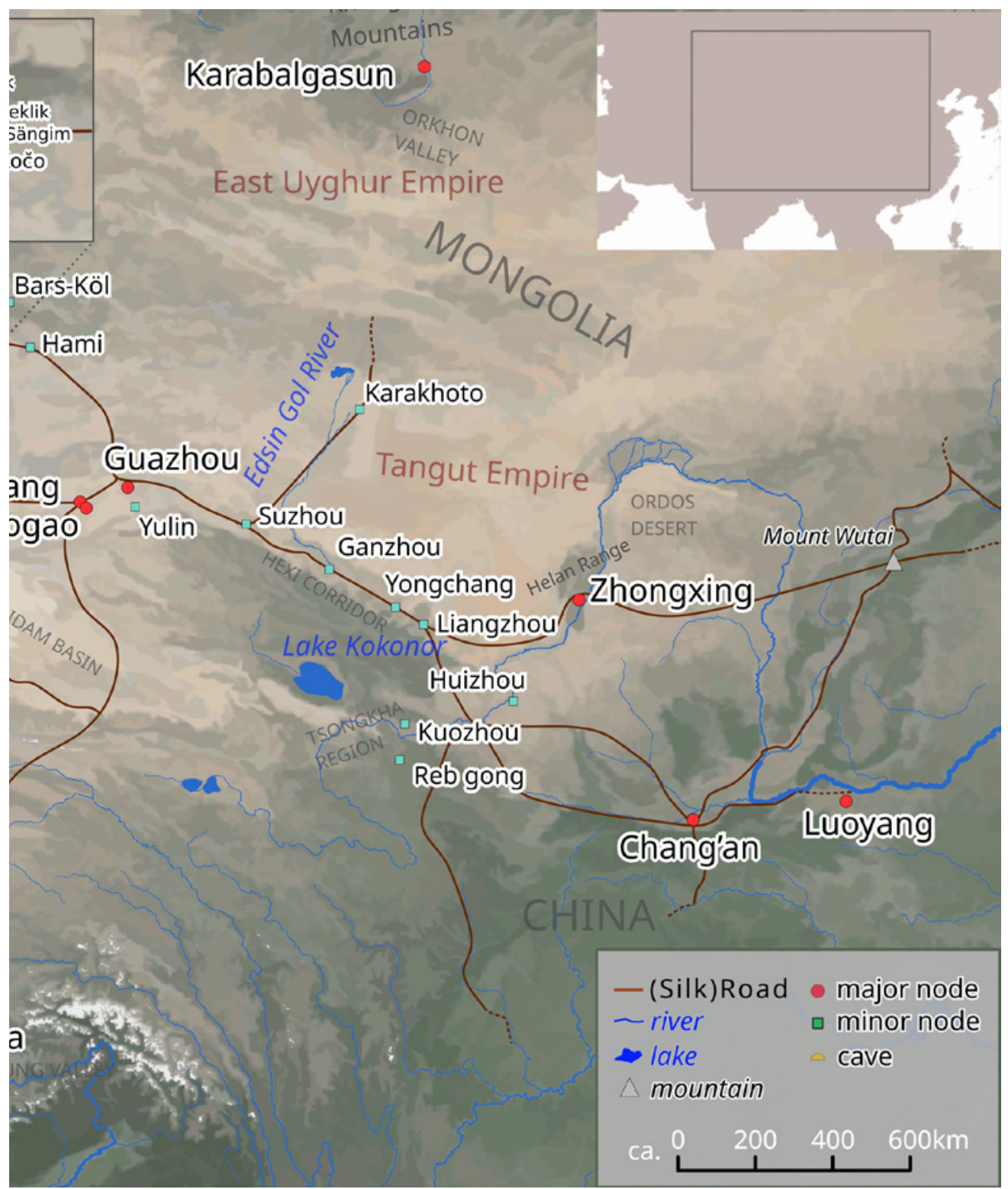


reflecting Sinitic cultural expansion westward. Even so, the manner in which these sites developed followed a particular mode of formation, which to a large extent depended upon the special religious, political, economic, and geographic factors that prevailed in the region for more than a millennium. Therefore, one can talk about these sacred spaces as emerging through a series of more or less conscious, cultural processes adapted to a specific geographical reality.

One may also observe how the interplay between the religious and secular spheres played out on the ground, i.e. among a given population at large. In the context of the concept of sacred space, this involves the production of Buddhist scriptures, education for monastics and commoners, and Buddhist participation in the local economy, which includes the operation of agricultural enterprises, pawnshops, loan businesses, etc. In short, in the sites where Buddhism thrived, the religion was essentially a civilising force, and as such a conveyor of traditional science and developer of material culture. Moreover, Buddhist societies served as a link between monastics and the general population at large.

The process of gradually developing and strengthening a network of sacred sites along pilgrimage routes (most often following established trade routes) tends to accelerate in times of peace and stability, which was the case for lengthy periods of time in Eastern Central Asia between the 6th and the 14th centuries. ${ }^{6}$ Due to strong patronage systems, sacred sites were maintained, cave sanctuaries were created, and old caves were renovated-e.g. such as we see in the proliferation of newly excavated family caves under the Zhang and Cao clans in Dunhuang during the 9th and 1oth centuries, or in the imperially sponsored renovations of caves and monasteries by the Tanguts at the height of their Empire in the 12th century. ${ }^{7}$ Workshops creating religious art and scriptoriums producing texts were professionalised-e.g. as visible in 1oth century Dunhuang, with the establishment of artisan workshops, or with the institutionalisation of translation processes of Buddhist scriptures in the Tangut Empire during the 11th century. ${ }^{8}$ As these and similar activities intensified, specific

6 For a further discussion of sacred sites and the emerging of pilgrimage routes along such sites see: Philippe Forêt and Andreas Kaplony, eds., The Journey of Maps and Images on the Silk Road (Leiden: Brill, 2008); particularly the following article in the volume: Natasha Heller, "Visualizing Pilgrimages and Mapping Experience," in The Journey of Maps and Images on the Silk Road, ed. Philippe Forêt and Andreas Kaplony (Leiden: Brill, 2008), 29-5o; Dorothy C. Wong, "A Reassessment of the Representation of Mt. Wutai from Dunhuang Cave 61," Archives of Asian Art 46 (1993): 27-52.

7 For the Tangut example see Chapter 10 by Carmen Meinert in this volume.

8 For the professionalisation of art workshops in 1oth century Dunhuang see Sarah E. Fraser, Performing the Visual: The Practice of Buddhist Wall Painting in China and Central Asia, 618-960 
sacred sites gained in attraction, which, in turn, increased the production of new religious materials and led to a need for more pilgrimage to take place. In other words, this was a mutually reinforcing process.

Broadly speaking, sacred space may be defined as a place where religious activity occurs on the part of religious agents. Such a place may be gradually perceived as sacred, and over the course of time, additional elements of sacredness may emerge, e.g. myths or charismatic leaders become associated with a given site, holy monuments are built, etc. Moreover, the sanctity of one site may be established or enhanced through exchange between two (or more) sacred sites at different locations, e.g. what is depicted in a given temple in Khotan may well be related to a wall painting in a cave in Dunhuang.

Pilgrimage, as it unfolded on the Silk Road, took on a variety of forms, exemplified by both those pilgrims who came from afar, such as from India, Khotan, or Tibet, and also those who came from the vicinity of the holy sites themselves, such as was the case with Dunhuang and a city like Kočo in the Turfan region, where the main cultural centres were a mere twenty-five to thirty kilometres away from the sacred sites. Pilgrims were, therefore, a motley crowd, representing a variety of cultures and from all kinds of social and religious backgrounds. This was the case even though the sacred sites that interest us here were all representative of the Buddhist religion.

The breadth of the topics sketched here and the variety of approaches to them are reflected in the range of contributions to the present volume. The group of contributors hail from diverse research fields and have an equally diverse range of philological capacities. This has produced a volume whose contents bridge the artificial boundaries between the various linguistic and cultural spheres presented here, and as such addresses many of the religious complexities of Eastern Central Asia between the 6th to 14th centuries. Moreover, scholars dealing with the themes of the conference, but not necessarily focusing on the project's main region, were also invited for the purpose of comparison.

The volume is made up of two parts: A part on patronage and legitimation and a part on sacred space and pilgrimage. In a general introductory chapter to the volume, Sem Vermeersch's "Who Is Legitimising Whom? On Justifying

(Stanford: Stanford University Press, 2004). When the Tanguts ordered between 1031-1073 six copies of the Chinese Buddhist canon from the imperially established Office for the Translation of Buddhist Scriptures (Chin. yijing yuan 譯經院) by the Song Dynasty (96o-1279, 宋), the Tanguts even copied that institutional model for the translation of the Buddhist canon from Chinese into Tangut in their capital. See Ruth W. Dunnell, The Great State of White and High. Buddhism and State Formation in Eleventh-Century Xia (Honolulu: University of Hawai'i Press, 1996), 36-49. 
Buddhism's Place in the Body Politic" investigates the concept of legitimation in East Asian Buddhism. He does so by questioning whether it was the religion that actually legitimatised the rulers or vice versa, or whether something else entirely was at play. He argues that often we cannot find well-defined and clear-cut sources underpinning Buddhist legitimation in the East Asian sources, but rather that historical precedent and local cultural and social factors were at play. He points out how recent innovative studies of personal devotion and related practices, based on archeological evidence, and neglected genres of texts, add new dimensions to the existing discours on legitimation. He then makes a critical re-evaluation of the concept of legitimation based on the application of a series of theorists, including Weber, Habermas, Moin, Foucault, etc., which leads Vermeersch to come up with a three-fold definition of power. Finally, the author concludes his excursus in 2oth century Western philosophy, ending with Ann Blackburn's theoretical musings on Buddhism and state-craft in East Asia. From this point onwards, Vermeersch's arguments increasingly focus on East Asian cases, elucidating the relationship between Buddhism and rulers in the form of a veritable tour de force from Tang (618-907, 唐) China over Nara (710-794, 奈良) Japan to Koryŏ (936-1392, 高麗國) Korea. Among other examples, he gives special attention to the Renwang jing 仁王經 [Scripture on the Humane Kings], a major scripture in traditional Buddhist legitimation discours. As a self-professed Wheel-Turning King (Skt. cakravartin) Empress Wu (r. 685-704, 武后) stands as a classical example of a Chinese ruler, who played on the supplied by Buddhism. The author concludes that although it is evident that the Buddhists sought to render legitimation to the Chinese emperor(s) through this apocrypha, in reality it could very well be a case of mutual legitimation. Ending his investigation in Korea, Vermeersch makes a detailed review of the case of King Hyŏnjong (r. 1009-1031, 顯宗), who used Buddhist texts and rituals based on the Scripture on the Humane Kings to strengthen his own legitimacy in times of crisis, and later extended his graces to Buddhist establishments, even sponsoring the carving of the first Korean tripitaka.

Moving to Eastern Central Asia, Chapter 2 "Images of Patronage in Khotan" by Erika Forte focuses on how patronage was expressed in the Buddhist-dominated Kingdom of Khotan (ca. 1st c.?-1006) mainly on the basis of archaeological discoveries. Forte shows that patronage-as expressed through material and visual culture by the Khotanese-made use of mythological imagery and certain cultural markers that were deeply steeped in Buddhist lore and belief, rather than presenting the local rulers as patrons of Buddhism or as integral parts of the religious iconography, as we see elsewhere. The author explores two important foundation myths that exemplify this mythological 
overlay and indirect patronage, namely the Silk Princess and the founding of the Gomatī Monastery. Forte highlights how these myths play out in relation to existing archaeology by identifing archaeological sites with the transmitted legends/myths, addressing Mt. Gautośan/Gośrnnga and Kohmārī Hill in the process.

Next follows "Uyghur Legitimation and the Role of Buddhism." Chapter 3 by Yukio Kasai is devoted to a discussion of the question of legitimation and patronage in the West Uyghur Kingdom, which flourished from the mid-gth century onwards in the Turfan oasis. Kasai shows that initially the Manichaean religion provided spiritual legitimation for the shifting Uyghur rulers, and was therefore favoured by them. However, the Uyghur rulers gradually changed their adherence away from Manichaeism towards Buddhism, a development that may have come about due to the increasing internationalisation of the Uyghurs themselves, fostered through their sustained contact with neighbouring cultures where Buddhism was the primary religious factor. Kasai explains that the transition from Manichaeanism to Buddhism did not happen overnight or through an immediate and calculated political process, but was a protracted affair that did not involve any overt forms of persecution. This is clear from the fact that both religions co-existed in the Uyghur Kingdom before Buddhism eventually became the dominant religious force. It appears that the decline of Manichaeism was to a large extent caused by the loss of patronage of the rulers and members of the upper echelons of Uyghur society. With this loss of influence, Manichaeism declined, and ruler's legitimation strategy shifted to the Buddhist model of the enlightened ruler, even though the sources do not allow us to conceptualise this as similar to the cakravartin-type of ruler imagery that we find in the Dunhuang material.

In Chapter 4 "Donors and Esoteric Buddhism in Dunhuang during the Reign of the Guiyijun" Henrik H. Sørensen looks at the relationship between secular power and Buddhism expressed in Esoteric Buddhist votive paintings produced as offerings for important local temples by rulers and families occupying the higher echelons of society in Dunhuang. These religious paintings, which were presented as gifts to various local temples, were partly used by their donors to highlight their status at the same time as they addressed various religious needs, including the desire to extend the religious merit thought to derive from such offerings to deceased relatives. These paintings-all of which reflect the popularity of certain Esoteric Buddhist cults, chiefly those associated with the all-important Bodhisattva Avalokiteśvara in his many forms - attest to the increasing significance of Esoteric Buddhism as a dominant tradition within Mahāyāna Buddhism, a tradition that took on a special significance in the Dunhuang Kingdom, due to its integration of several waves 
of transmission that represented virtually all the cultures in the region. Therefore, this form of Buddhism, which obviously enjoyed both an inter-cultural and also an international appeal in the region, was well-suited to function as a common denominator for believers inhabiting wide swaths of Eastern Central Asia. In Dunhuang, situated at a strategic point on the eastern stretches of the Silk Road, the ruling Cao clan (曹氏) was obviously part of this trend. It is, therefore, no coincidence that its members sought to capitalise politically as well as religiously on this commonality in their self-representation as Buddhist devotees and donors.

The final chapter in the part on patronage and legitimation by Kirill Solonin, "Formation of Tangut Ideology: Buddhism and Confucianism," is devoted to a discussion and presentation of the legitimation strategies that unfolded in the Tangut Empire (ca. 1038-1227, in Chinese sources known as Xixia 西夏) through the utilisation of what the author sees as a conscious cultural and civilising approach to nation-building. The Tanguts, a relatively new nation and a selfconscious one at that, while on the one hand wishing to appear both civilised and as equals in cultural terms vis-à-vis its Chinese and sinicised neighbours, were quite willing to adopt salient features of Chinese political and civil culture; on the other hand, they were equally concerned with the preservation of what they saw as their own cultural roots. This two-pronged strategy appears to have been quite successful. The Tanguts never abandoned their deep-felt attachment to Buddhism but instead sought to integrate and develop said strategy under the aegis of Buddhism. They did this in such a manner that the other civilising forces represented by their native literature (mainly in the form of a song or hymn-tradition) and Confucianism-based education (chiefly meant for its civil servants) continued to be fully functional and operative. In the course of his discussion, Solonin presents a series of representative and central primary sources with which he underscores his arguments and findings.

Moving to the part on sacred space and pilgrimage, Chapter 6 "From Padmasambhava to Gö Tsangpa: Rethinking Religious Patronage in the Indian Himalayas between the 8th and 13th Centuries" by Verena Widorn treats the interactions between (semi-)historical human agents, physical spaces, and monuments in the creation of sacred landscape of in the Western Himalayan regions of Kinnaur and Lahul (part of the contemporary Indian state Himachal Pradesh and on the former Tibetan periphery). Widorn relates how hagiographic narratives of three important Buddhist agents are employed in order to sanctify religious sites - namely the semi-historical, pivotal figure for the Nyingma School (Tib. rnying ma pa), Padmasambhava (8th c.), Rinchen Zangpo (ca. 985-1055, Tib. Rin chen bzang po), a central figure during the 
post-imperial restoration of Buddhism in the Western Tibetan Kingdom of Purang-Guge, and the yogi and pilgrim of the Drukpa Kagyü School (Tib. 'brug pa bka'brgyud pa), Gö Tsangpa (ca. 1189-1258, Tib. rGod tshang pa), all three of whom have been-and still function as - patrons in the Western Himalayas. Through trans-regional exchanges, the legacies of all three have contributed to the construction of a Tibetan Buddhist artistic heritage in the region, as well as to the development of a regional network of sacred sites, in certain cases still extant.

With Chapter 7 "Sacred Space in Uyghur Buddhism" by Jens Wilkens and Chapter 8 "Pilgrims in Old Uyghur Inscriptions: A Glimpse behind Their Records" by Simone-Christiane Raschmann, the volume moves again to the core region of the BuddhistRoad project, the Tarim Basin. Both chapters focus on the Old Uyghur materials in order to elucidate how concepts of sanctity and pilgrimage were understood and played out among the multi-religious Uyghurs.

Wilkens shows how Uyghurs, upon their migration into the Turfan region, positioned themselves in a Buddhist environment, partly adapting and reformulating Buddhist concepts of holiness. However, other terminologies tended to mirror the Uyghurs' self-perception as a distinct cultural group. Attributes of holiness appear in royal titles and are also attributed to physical space (e.g. to the winter capital of Kočo). The old sacred centre of the Turkic peoples in the region of Ötükän shifted with the migration to the Turfan region in the vicinity of the new summer capital Beš Balık. The Uyghurs' understanding of sacred space can thus be analysed through their original compositions, such as poems and inscriptions.

Raschmann's investigation of the records of Uyghur pilgrims proves the extent to which Uyghurs participated in the larger Buddhist network of sacred sites through pilgrimages in the region, e.g. as visible in Old Uyghur inscriptions in the Mogao and Yulin Caves (as evidence for regional pilgrimage) and in an eulogy of Mt. Wutai (as a proof for trans-regional pilgrimage). Moreover, her case study on inscriptions from ruin Q in Kočo shows that it was originally a stūpa, and as such was upheld as an extraordinary and sacred site in Kočo, worthy of receiving pilgrims from near and far.

Chapter 9 "Looking from the Periphery: Some Additional Thoughts on Yulin Cave 3" by Max Deeg was originally a response to a conference paper by Michelle McCoy. From the perspective of a textual scholar, Deeg analyses the main figures in a diptych of Samantabhadra and Mañjuśrī, and the pan-Buddhist narrative background of Yulin Cave 3, which was produced during the Tangut Empire (ca. 1038-1227). The Tangut patrons successfully reformulated and intertwinted the concepts, elements, and narratives of e.g. a proto-Xiyou ji 西遊記 [Record of the Journey to the West] context, originally a Nepalese 
narrative about Mañjuśrī, who cuts a hole into the mountains with his sword to release the water from the primordial lake in the Kathmandu Basin. By weaving narrative ingredients and motifs into a dense patchwork, they created a Tangut Buddhist identity of their own.

In the final chapter, Chapter 10 "Creation of Tantric Sacred Spaces in Eastern Central Asia," Carmen Meinert explores the relationship between Tangut imperial patronage of Tibetan Tantric masters, the teachings and related religious art, and the deliberate construction of a network of Tantric Buddhist sites throughout the Tangut Empire during the late 12th century. She draws on visual and material evidence to demonstrate that the Tangut Emperor Renzong (r. 1139-1193, 仁宗) acted as a patron of Buddhism not only in his capacity as a Buddhist ruler of the Tanguts but also as an expression of his personal desire to show himself as a Buddhist initiate. As part of this process, he produced a new visual imagery in the major nodes of his empire, a trend that was reproduced in minor nodes. Meinert's discussion moves from the micro-level of analysis of specific art objects, to the relation of those objects with similar ones found at other sites, thereby creating a network of sacred sites related to Tantric Buddhism within the Tangut territory at large. 
PART 1

Patronage and Legitimation 